\title{
Yükseköğretim Kurumlarında Sosyal Kaytarma Davranışının İncelenmesi: Bir Kamu Üniversitesi Örneği
}

\section{Investigating Social Loafing Behavior in Higher Education Institutes: A Case of Public University}

\author{
Melahat Öneren a , Elif Nur Demirel ${ }^{\mathrm{b}}$, Tayfun Arar ${ }^{\mathrm{c}, *},{ }^{*}$ Cihat Kartal ${ }^{\mathrm{d}}$ \\ ${ }^{a}$ Dr. Öğr. Üyesi, Kırıkkale Üniversitesi, İktisadi ve İdari Bilimler Fakültesi, İşletme Bölümü, 71450, Kırıkkale/Türkiye. \\ ORCID: 0000-0002-4255-9422
}

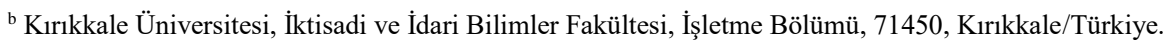
ORCID: 0000-0002-8453-5867

c Arş. Gör., Kırıkkale Üniversitesi, İktisadi ve İdari Bilimler Fakültesi, İşletme Bölümü, 71450, Kırıkkale/Türkiye. ORCID: 0000-0001-6132-1121

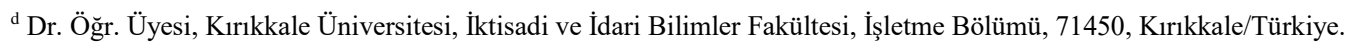
ORCID: 0000-0003-2390-8268

\section{MAKALE BILGİSI}

\section{Makale Geçmişi:}

Başvuru tarihi: 28 Mayıs 2018

Düzeltme tarihi: 12 Temmuz 2018

Kabul tarihi: 06 Ağustos 2018

\section{Anahtar Kelimeler:}

Sosyal Kaytarma

Analitik Hiyerarşi Prosesi (AHP)

Akademik Personel

\section{ARTICLE INFO}

\section{Article history:}

Received May 28, 2018

Received in revised form July 12, 2018

Accepted August 06, 2018

\section{Keywords:}

Social Loafing

Analytic Hierarchy Process (AHP)

Academic Staff
ÖZ

Bu araştırmanın amacı sosyal kaytarma davranışını etkileyen faktörleri önem sırasına göre hiyerarşik olarak sıralayarak, bu tür faktörlere bağlı olarak ortaya konan sosyal kaytarma davranışına karşı önlem alma ve bu faktörlerden kaynaklı sosyal kaytarma davranışını yönetme eylemleri sunmaktır. $\mathrm{Bu}$ bağlamda bir kamu üniversitesindeki 11 akademisyen, literatür ve yazar destekli olarak belirlenmiş üç ana faktör altındaki 19 faktörü ikili olarak karşılaştırmış ve karşılaştırılan bu kriterler Analitik Hiyerarşi Prosesi (AHP) tekniği ile hiyerarşik olarak sıralanmıştır. Araştırma, akademisyenler tarafindan ileri sürülen sosyal kaytarmayı etkileyici faktörlerin belirlenmesi ve böylesine üretkenlik karşıtı davranışlar üzerinde etkili olan faktörlere bağlı olarak nasıl önlenebileceği konusunda yol gösterici olması açısından önemlidir.

\section{A B S TR A C T}

The purpose of this study is to order the factors determining social loafing hierarchically based on their importance levels, and then suggest cautions against social loafing caused by those factors and managing social loafing actions caused by them. In this concept, 11 academic staff in a public university, have made pairwise comparisons of 19 factors under three main factors determined by both literature and authors, and these compared factors are analyzed and ordered by Analytic Hierarchy Process (AHP) method. The research is important in terms of determining the social loafing factors proposed by academicians and determining how to prevent them depending on the factors that influence this counterproductive behaviors.

\section{Giriş}

Sosyal kaytarma, sosyal psikoloji ve işletme gibi bilim alanlarında akademik çerçevede çalışılan, aydınlatıcı bilgilerin sunulduğu güncel bir olgudur. Sosyal kaytarma genel anlamda ortak çaba ile yapılması gereken bir işin grup üyeleri tarafından tam olarak sahiplenilmemesi, bireysel olarak ortaya koydukları çabanın grup içinde azalması olarak nitelenebilir. Örgütlerde çalışma oldukça sistematik işlemesi gereken ve bireylerin görev ve sorumluluklarını iyi bir şekilde yapmalarını gerektiren bir süreçtir. Örgütlerin varlıklarını sürdürebilmek ve mevcut kalitesini artırabilmek adına attığı adımlardan bir tanesi de insan kaynaklarının niteliği ve çalışma isteğidir. Kalifiye işgörenin iş ortamına uyumunun sağlanması, azami düzeyde verimliliğin elde

\footnotetext{
* Sorumlu yazar/Corresponding author.

e-posta: tayfunarar@kku.edu.tr
} 
edilmesi başta özel sektör olmak üzere kamu sektöründe de belirleyici kriterlerdendir.

Örgütlerde başarının belirleyicisi olan performansın sağlanması temel hedeftir. Bireysel özellikler ve faktörler dışında başarının dinamiklerinden bir tanesinin de ekip/grup çalışmaları olduğu ifade edilebilir. Üniversiteler de akademik personel arasında grup çalışmalarının yapıldığı, eş güdüm temelinde ders paylaşımlarının hedeflendiği, ortak yayın ve kongre programlarının yürütüldüğü ve genel manada akademik kalitenin artırılması için birlikte hareket edilen örgütlerdendir (Çelikten, 2003: 101-102). Kongre düzenleme komiteleri, bilimsel yayınlarda birçok yazarın yer alması, her akademik bölümün (programın) birden fazla öğretim elemanı tarafından yürütülmesi ortak çalışmanın gerekliliğini ortaya koyan başlıca konular olarak ifade edilebilir (Karaman ve Altunoğlu, 2007: 112; Acar, Nemutlu, Gürhan ve Liman, 2004: 96; Baş, 2002: 28; Gencel, 2001: 207).

Örgütsel çalışmalar ya da grupla birlikte yapılan çalışmalarda ortak hedef; verimin artırılması, hızlı sonuç elde edilmesi ve başarıya ulaşılması olarak beklenir. $\mathrm{Bu}$ beklentinin gerçekleşmemesinin nedenlerinden bir tanesi de sosyal kaytarma davranışı olarak nitelenebilir. Sosyal kaytarma, grupsal olarak çaba gerektiren işlerde bireysel performansta azalma olarak tanımlanmıştır (Latane, Williams ve Arkins, 1979: 823). İkinci bir tanıma göre; sosyal kaytarma, bireylerin grup halinde çalışırken ortaya koydukları performansın bireysel olarak çalışırken gösterdikleri performansa göre nispeten daha düşük olmasıdır (Kafes ve Kaya, 2017: 227). Bu bağlamda, sosyal kaytarmanın negatif yönlü bir sinerjik etki yarattığ söylenebilir. Grup içinde yapılacak görevlerde bireyin kendi üzerine düşeni tam olarak yerine getirememesi sonucunda bu durumun diğer grup üyeleri tarafından tolere edilebileceğini düşünmesi ve aynı sorumluluğun birden fazla bireye verilmesi halinde kişisel katkının gereksiz olduğu düşüncesi de sosyal kaytarma davranışının ortaya konulmasında etkileyici olabilir (Uslu ve Çavuş, 2014: 52). Başka bir ifade ile bireylerin kişisel işleri üzerinde yoğunlaştığ 1 , emek verdiği, önemsediği kadar grup çalışmalarını, örgütsel çalışmaları önemsememesi ve gruptaki diğer bireylerin de bu şekilde davrandığını düşünerek minimum destek ile örgüt çalışmalarını yürütmesine yine sosyal kaytarma denilebilir.

Daha önce de belirtilen; üniversiteler takım çalışmasının sıkça yapıldığı, kaliteli ürünlerin kümülatif ve sinerjik bir etki ile ekip çalışmasıyla beraber ortaya çıktığı kurumlardır bilgisinden yola çıkarak, grup çalışmalarındaki davranışları olumsuz etkileyen unsurlardan birinin de sosyal kaytarma davranışı olduğu gerçeğinin altını çizerek bu tür davranışları önem sırasına göre sıralamak, proaktif önlemler ve reaktif çözüm önerileri sunmak çalışmanın temel amacını oluşturmaktadır. Daha çok insana özgü bir eğilim olan sosyal kaytarma davranışlarını etkileyen birçok faktör vardır. Örgütsel ve yönetsel bazda, tüm bu faktörler ile başa çıkmak ve yönetmek veya bu faktörleri önlemek, zahmetli ve maliyetli olacağından rasyonel değildir. Özellikle, Şekil 1 'de belirtilen örgütsel faktörlerin tümüne yönelik bir iyileştirme, örgüt çapında farklı sistemlerde yapısal reformlar gerektirebilmektedir. Ayrıca bireysel faktörlere yönelik, işe alım aşamasında önlem alınmaktansa, bu tür davranışlar ortaya çıktıktan sonra belirtilmiş olan bazı faktörlerin (cinsiyet, kişilik ve kültür) değiştirilmesinin mümkün olmaması, çözümün ișten çıkarma olması ve tüm bu süreçte işgörenin yetiştirilmesi ve eğitilmesi için yapılmış olan maliyetler yüksek oranlarda olacağından, bu çalışmada sosyal kaytarma davranışlarını etkileyen faktörleri AHP yöntemi ile hiyerarşik olarak sıralama yoluna gidilmiştir. AHP yönteminin tercih edilmesi, zaman kısıtı gerekçesi ile tüm faktörlerin değerlendirmeye alınmasından ziyade sosyal kaytarma davranışı üzerinde en fazla etkisi olan ana faktörlerin belirlenmesine katkı sağlamıştır. Bu sayede, olumsuz sonuçlar doğuran böyle bir olguyu tetikleyen en önemli faktörün/faktörlerin önüne geçildiğinde olgunun ortaya çıkma ihtimali de nispeten daha az emek ve maliyetle azalmış olacaktır.

\section{Sosyal Kaytarma Kavramı ve Yapılan Akademik Çalışmalar}

Sosyal kaytarma yazında Ringelmann Etkisi olarak da bilinmektedir (Schermerhorn vd., 2008: 172'den aktaran: Demir Uslu ve Çavuş, 2014: 52). Bu alanda sosyal psikolojik ilk çalışma 1880'lerde bir halat çekme görevinde ortaklaşa çalışmanın etkilerini inceleyen Ringelmann tarafindan gerçekleştirilmiştir (Williams ve Karau, 1991: 573). Kavramın bu isimle anılmasının sebebi ise; Fransız ziraat mühendisi olan Max Ringelmann'ın 20 kişiyle gerçekleştirdiği halat çekme deneyinde, halatın ucuna bağlanan dinamometre ile kişilerin bireysel ve grup halinde iken halat çekme kuvvetlerini ölçmüş ve gruptaki kişi sayısının arttıkça dinamometreye binen kişi başı çekme kuvvetinin düştüğünü saptamış olmasıdır (Simms ve Nichols, 2014: 59). Ringelmann gruptaki birey sayısı arttıkça toplam performansın da ters orantılı olarak düştüğünü belirlemiştir. Grup büyüklüğü ile harcanan çaba arasındaki bu kavramsallaştıma "Ringelmann Etkisi" olarak adlandırılmaktadır (Piezon ve Ferree, 2008: 2).

1972 y1lında Steiner sosyal kaytarma teorisine yeni bir ilgi alanı eklemiştir. Araştırmasında doğrudan Ringelmann' in çalışmasına değinmesinin dışında, süreç kaybı olarak nitelendirdiği bir görev tipolojisini açıklamaya eğilmiştir. Steiner çalışmasında gerçek grup verimliliğinin, potansiyel grup verimliliği ile hatalı süreçten kaynaklanan kayıplar arasındaki farklara eşit olduğunu iddia etmiştir (Kesen, 2015: 6532). Ingham vd. (1974) Ringelmann etkisini grup performansı ve grup büyüklüğü üzerinde tekrar incelemişlerdir. Ringelmann'ın halat çekme deneyinin bir benzerini gerçekleştirmişlerdir. Yapılan deneyde bireyler grup halinde halat çekerken maksimum performans göstermeleri talep edilmiştir. Hem grup içinde hem de bireysel halat çekme aktiviteleri arasında bireylerin grup halinde iken bireysel duruma kıyasla 1/5 oranında daha az çaba harcadıkları belirlenmiştir (Ingham vd., 1974: 371). Latane vd. (1979) çalışmasında sosyal kaytarmaya ilişkin bir başka deney gerçekleşmiştir. Bu deney bireylerin grup halinde alkışlamalarını içeren bir deneydir. Deney sonucunda, gruptaki kişi sayısı arttıkça katılımcıların her birinin bireysel olarak yaptıkları alkış gürültüsünün grup içinde şiddetinin azaldığı belirlenmiş, bireylerin grup halinde iken çabalarındaki azalmayı bilimsel bir deneyle açıklamış ve sosyal kaytarmayı "çalışma grubu içerisinde bireyin, aynı görevi yapan diğer bireylerle kıyaslandığında çabasını düşürme eğilimi”" olarak ifade etmiştir (Latane vd., 1979'den aktaran: Schippers, 2014: 62). Sosyal kaytarma (social loafing) isminin ilk kez kullanıldığı bu çalışmada 
sosyal kaytarma "toplumsal bir hastalık" olarak nitelendirilmiştir (Ilgın, 2013: 241).

Sosyal kaytarma davranışının örgüt yapısı ve örgüt işleyişine zararları konusunda iş veriminin azalması, iş barışının bozulması, çalışanlarda tükenmişlik sendromu, üretim faaliyetlerinin sekteye uğraması ve performanstaki düşüşe dayalı maliyetlerin artış gösterdiği sonuçlarına ulaşılmıştır (Ilgın, 2013: 239; Uysal, 2016: 735; Uslu ve Çavuş, 2014: 53; Karau ve Williams, 1993: 694; Özmutaf, 2007: 50).

Sosyal kaytarmanın gelişiminde farklı deneyler ya da çalışmalar yapılmasının yanı sıra sosyal kaytarmanın kavramsallaşması ve bir teori olarak anılmasında yukarıda bahsedilen temel noktaların önemli rol oynadığı söylenebilir. Literatürde sosyal kaytarma üzerine birçok çalışma yapılmıştır. Yapılan çalışmalarda sosyal kaytarma üzerinde etkili olan faktörlerin belirlenmesi ve çeşitli çalışma grupları üzerinde sınanmasına odaklanılmıştır (Alam, Ali, Ali ve Zaman, 2014: 78; Etemadi, Darab, Khorasani, Moradi ve Vazirinasab, 2015: 125; Uslu ve Çavuş, 2014: 51; Uysal, 2016: 735; Kafes ve Kaya, 2017: 229; Şeşen ve Kahraman, 2014: 43). Çalışmaların genelinde sosyal kaytarmanın olumsuz bir durum olduğu vurgusuna yer verilirken sosyal kaytarma davranışının üzerinde bireysel, örgütsel ve grupsal faktörlerin etkili olduğu ifade edilmiştir (Ilgın, 2013: 241255-260; Karau ve Williams, 1993: 694). Bu faktörlerin yanı sıra sosyal kaytarmanın 'örgütsel adalet' kavramı ile de çok bağlantılı olduğunu paylaşan literatür çalışmaları mevcuttur (Uslu ve Çavuş, 2014: 53; Alam vd., 2014: 89; Etemadi vd., 2015: 128). Koçel (2014: 530), örgütsel adalet kavramını bir organizasyondaki uygulamaların dayandığı ilkelerin net olmasını, bireyden bireye farklı uygulamalar olmamasını, olsa bile bunun nedenlerinin şeffaf bir şekilde açıklanmasını öngören bir kavram olarak açıklamıştır. Balcı (2016: 36), bireyin örgütsel adalete ilişkin algısı pozitif ise bu örgüte güven ile birlikte bireysel motivasyonda da artışa katkı sağlayacaktır. Örgütsel adalete ilişkin negatif alg1 söz konusu ise bu durum bireyde iş tatminsizliğinden işten ayrılmaya kadar uzanan tutumlara yol açacaktır. Buradan hareketle örgütsel adalet olgusunun, çalışma sürecinde performansı doğrudan etkilediği ifade edilebilir. Örgütsel çalışma gerektiren işlerde örgütsel adaletin sağlanması önemli bir husus olarak karşımıza çıkarken yönetici/idareci pozisyonundaki kimselerin çalışanlarını motive edici uygulamalarda bulunmaları da önem arz etmektedir. George (1995), örgütsel adalet teorisine paralel olarak yöneticinin/idarecinin, çalışanlarını ödül ile motive etmesini sosyal kaytarmayı azaltan önemli bir etken olarak ifade etmiştir (Balcı, 2016: 98).

Literatürde yer alan diğer akademik çalışmalardan hareketle; Hoigaard ve Ingvaldsen (2006: 58) tarafindan lisans eğitimine devam eden 24 erkek öğrenci ile bir sosyal kaytarma çalışması gerçekleştirilmiştir. Bu çalışmada takım içinde kimin hangi düzeyde çaba gösterdiği ve performans sergilediğinin belirlenmesinin sporcu öğrencilerin takım içinde sosyal kaytarma davranışını sergilemeye yönelik algılarını ölçmüştür. Araştırma sonucunda bireylerin performansının doğrudan ölçülebilmesinin sosyal kaytarma davranışını azalttığı bulunmuştur. Sosyal kaytarmaya olan eğilimin cinsiyete bağlı olarak farklılaştığı; aksine cinsiyete bağlı farkın bulunmadığı çalışmalar da literatürde yer almaktadır. Karau ve Williams (1993: 694) ve Öge ve Kurnaz’a (2017: 123) göre sosyal kaytarma davranış1 eğiliminin kadınlara göre erkeklerde fazla olduğu ifade edilirken; Charbonnier vd. (1998), tarafından 36's1 kadın 36's1 erkek olmak üzere 72 lisans öğrencisi üzerinde yapılan araştırmada, sosyal kaytarma davranışının gösterilmesinde cinsiyetin etkisinin olmadığı tespit edilmiştir (Doğan vd., 2012: 63).

Bununla birlikte Thompson ve Thornton (2014: 475-479) tarafından okul öncesi çocuklar üzerinde (59 kız, 47 erkek deneysel bir laboratuvar çalışması gerçekleştirilmiştir. Grup görevlerinde daha az çaba harcanması (sosyal kaytarma) kız çocuklarında erkeklere göre biraz daha yüksek olarak belirlenmiştir. Eikenhout (2004: 48) tarafından yapılan başka bir çalışmada katılımcıların belirli bir görevi yapmak üzere ortaya koydukları bireysel çabayı, sonuçları grup halinde görünecek olan bir çalışmaya çevirmeleri durumunda ortaya koydukları performansta azalma olduğu belirlenmiştir. Buna bağlı olarak bireysel durumların daha geri planda olduğu hallerde sosyal kaytarma davranışının ortaya çıktığı ifade edilebilir. 2016 yılında Haugen vd. (2016: 308) tarafindan sosyal kaytarma odağında gerçekleştirilen bir diğer çalışmada zihinsel dayanıklılık ve sosyal kaytarma arasındaki ilişki incelenmiştir. Zihinsel dayanıklılık noktasında daha zayıf durumda olanların grup içinde performanslarını düşürerek sosyal kaytarma davranışı ortaya koydukları belirlenmiştir. 2014 yılında Şeşen ve Kahraman (2014) tarafından yapılan bir araştırmada ise iş arkadaşlarının kaytarmasının bireyin iş tatmini, örgütsel bağlılık ve kendi kaytarma davranışına etkisini incelemiştir. Teknik bir lisede çalışan 175 öğretmenin katılımıyla gerçekleşen bu çalışma sonucunda kişilerin iş arkadaşlarının kaytarma davranışı sergilediğini gördüklerinde kendilerinin de kaytarmaya yöneldikleri tespit edilmiştir. Ayrıca iş tatmini ve örgütsel bağlılıklarında da azalma olduğu sonucuna ulaşılmıştır. Sosyal kaytarma algısının çalışanların tükenmişlik duygularına etkisinin araştırılması amacıyla Uysal (2016: 738) da bir kamu kurumunda 108 çalışana bir anket uygulamıştır. Bu anket uygulaması sonucunda sosyal kaytarma algısı ile tükenmişlik duygusu arasında pozitif yönlü bir ilişki saptanmıştır. Sosyal kaytarma ile ilgili bir diğer araştırma ise Gök ve Koca (2016) tarafindan gerçekleştirilmiştir. Sağlık çalışanlarına uygulanan bir anket ile hiyerarşi ve takım eğiliminin sosyal kaytarmaya etkisi incelenmiş, sonuç olarak takım eğilimi arttıkça sosyal kaytarmanın azaldığı tespit edilmiştir. Hiyerarşik eğilimin ise sosyal kaytarma üzerinde herhangi bir etkisi olmadığı sonucuna ulaşılmıştır.

$\mathrm{Bu}$ değerlendirmeler neticesinde sosyal kaytarma davranışının içinde bulunan örgüt ve örgütsel adalet sistemi ile bağlantılı olduğu da söylenebilir. Literatür taramasından yapılacak bir diğer çıkarım ise bireylerin sosyal kaytarma davranışını ortaya koymasında bireysel, gruba bağlı etkenler ve örgütsel faktörler gibi nedenlerin etkili olduğudur. $\mathrm{Bu}$ çalışma özelinde ise bir kamu üniversitesinde görev yapan akademisyenlerin sosyal kaytarmaya dair görüşleri ön plana çıkarılmıştır. Buna bağlı olarak da akademik camiada sosyal kaytarma davranışının önlenmesi ya da azaltılması hususunda yol gösterici olmak adına literatüre katkı sunulması beklenmektedir.

\section{Yöntem ve Uygulama}

Bu çalışmada, literatür odaklı (Kafes ve Kaya, 2017; Doğan vd., 2012; Kesen, 2015; Şeşen ve Kahraman, 2014; Ilgın, 
2013; Uysal, 2017; Karau ve Hart, 1998; Karau ve Williams, 1993) ve yazarların katkılarıyla belirlenmiş olan sosyal kaytarma davranışlarına etki eden faktörler grup/ekip çalışmasının önem arz ettiği örgüt olan bir kamu üniversitesindeki akademisyenler tarafından hiyerarşik olarak sıraya konulmuştur. Şekil 1'de de görüleceği üzere sosyal kaytarma davranışları bireysel, grupsal ve örgütsel olmak üzere üç ana başlık altında toplanırken; bireysel faktörlerin altında cinsiyet, kıdem-unvan, kişilik, kültür, tükenmişlik seviyesi ve örgütsel bağlılık şeklinde 6 alt faktör, grupsal faktörlerin altında diğer grup üyelerinin sosyal kaytarma davranışı sergilemesi, kişilerarası güven, kişilerarası koordinasyon eksikliği, grup içinde bireyin çabasının önemsenmemesi, grubun büyüklüğü, rol belirsizliği, grup kaynaşması ve amaç birliği düşüncesinin yoksunluğu şeklinde 8 alt faktör ve örgütsel faktörlerin çalışma koşulları, ödül sisteminin yoksunluğu, ödüllendirmede örgütsel adaletsizlik, örgütsel kültür ve grup içi ve gruplar arası rekabet seviyesi şeklinde 5 alt faktör olmak üzere toplamda 19 alt faktör kodları ile belirlenmiştir.

Belirlenmiş olan bu faktörlerin hiyerarşik olarak sıralanabilmesi adına öncelikle bir kamu üniversitesindeki 11 akademik personel (4 Dr. Öğr. Üyesi, 4 Öğr. Görevlisi ve 1 Prof. Dr.) ile gönüllülük esasına dayalı olarak 15-04.2018 ve 01.05.2018 tarihleri arasında yüz yüze görüşme yolu ile faktörler önem derecelerine göre ikili karşılaştırılmıştır. Akademisyenler tarafından yapılan ikili karşılaştırmalar ise Analitik Hiyerarşi Prosesi (AHP) tekniği ile analiz edilmiştir. Burada belirtilmesi gereken önemli bir husus; nicel yöntemlerde güvenirlik ve geçerlik hususları genelde katılımcı sayısı ile doğru oranda artarken, AHP gibi Çok Kriterli Karar Verme tekniklerinde tutarlılık adı altında ele alınan bu husus katılımcının niteliği ile sağlanmaktadır (Triantaphyllou ve Mann, 1995: 37; Surapati ve Mukhopadhyaya, 2011: 26). Bu bağlamda çalışmamızdaki katılımcıların akademik kimlikleri ile yönteme yatkınlığı ve çalışma kapsamında ele alınan konu olan sosyal kaytarma davranışlarının ekip çalışmalarında görülmelerini mesleki faktörlerden dolayı deneyimleme ihtimalinin yüksek oluşu nitelik çerçevesini doldurmaktadır. Katılımcıların akademisyenlerden seçilmesindeki temel gerekçe ise multidisipliner çalışmalar yapan bir meslek grubu olmalarının yanı sıra eğitim seviyesi yüksek bir kitle olmalarından dolayı sürece dair net bilgilere ulaşılacağının düşünülmesidir.
Şekil 1. Sosyal Kaytarma Davranışını Belirleyen Faktörler

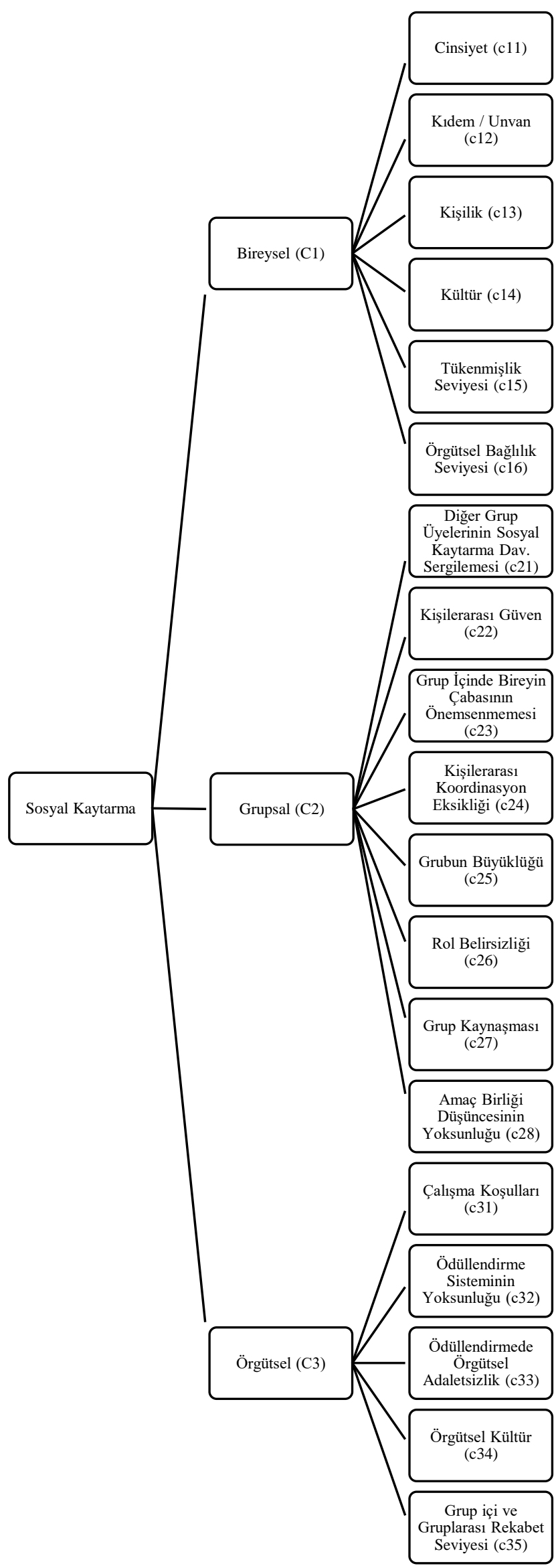




\section{Analitik Hiyerarşi Prosesi (AHP)}

Analitik Hiyerarşi Prosesi, alınması gereken kararlarda birden fazla faktör etkili olurken ve her bir faktörün önem derecesi eşit olmadığı zamanlarda kullanılan ikili karşılaştırma esasına dayanan Çok Kriterli Karar Verme (ÇKKV) tekniklerinden bir tanesidir. 1977 yılında Thomas L. Saaty tarafindan öne sürülen yöntem aynı anda nicel ve nitel değişkenleri bir arada incelenmesi için firsat vermesinden (Dong ve Cooper, 2016: 525), duyarlılık analizinin yapılmasına olanak sağlamasından (Ünal, 2011: 18) ve öznel yargıların analizde kullanılabilmesinden (Saaty ve Zoffer, 2012: 218) ötürü literatürde en çok kullanılan ÇKKV tekniklerinin başında gelmektedir.

Analitik Hiyerarşi Prosesi yönteminin temelde dört ilkesi bulunmaktadır. Bunlar; kriterlerin ikili karşılaştırma esasında a kriterinin $b$ kriterine göre önem derecesi $x$ iken $b$ kriterinin a kriterine göre önem derecesinin $1 / x$ olduğu belirten karşıtlık ilkesi, karşılaştırılan kriterlerin benzer özellikler taşımasını öngören homojenlik ilkesi, kriterler arasında herhangi bir ilişki olmadığının varsayıldığı bağımsızlık ilkesi ve en nihayetinde karar problemi çerçevesinde amacı etkileyen tüm faktör (kriter) ve alternatiflerin hiyerarşideki sıralamada konumlanmasını öngören beklenti ilkesidir (Saaty, 1991: 2-4).

$\mathrm{Bu}$ yöntemde kriterler aşağıdaki tabloda belirtilen hususlar çerçevesinde ve puanlar ile ikili karşılaştırılır.

Tablo 1. İkili Karşılaştırma Skalası

\begin{tabular}{|c|c|c|}
\hline & Tanım & Açıklama \\
\hline 1 & Eșit Derecede Önem & İki kriterin amaca yönelik ağırlığ 1 eşit \\
\hline 2 & Zayıf Önem & Deneyim ve Yargilama \\
\hline & Ilımlı Derecede & Bir kriter diğer kriterden amaca \\
\hline 3 & Önemli & yönelik olarak az önemli \\
\hline 4 & Daha Ilımlı & Deneyim ve Yargilama \\
\hline 5 & Önemli & $\begin{array}{l}\text { Bir kriter diğer kriterden amaca } \\
\text { yönelik olarak önemli }\end{array}$ \\
\hline 6 & Daha Önemli & Deneyim ve Yargilama \\
\hline 7 & Çok Önemli & $\begin{array}{l}\text { Bir kriter diğer kriterden amaca } \\
\text { yönelik olarak çok önemli }\end{array}$ \\
\hline 8 & Çok Daha Önemli & Deneyim ve Yargılama \\
\hline 9 & Kesinlikle Önemli & $\begin{array}{l}\text { Bir kriter diğer kriterden amaca } \\
\text { yönelik olarak kesinlikle önemli }\end{array}$ \\
\hline
\end{tabular}

Kaynak: KC vd. (2014: 219)

Yöntemin uygulanması aşamasında belirli adımları bulunmaktadır. Bu adımlar sırasıyla amaç başta olacak şekilde kriterler, varsa alt kriterler ve yine varsa alternatifler olacak şekilde hiyerarşik yapının oluşturulması adımı, ana ve varsa alt kriterlerin karşıtlık ilkesine dayanarak karşılaştırıldığı ikili karşılaştırma matrislerinin oluşturulması aşaması, aşağıda belirtilmiş olan eşitlik (1) yardımı ile kriterlerin ağırlıklarının hesaplandığı öncelik vektörlerinin hesaplanması aşaması, aşağıda belirtilmiş olan eşitlik (2, 3 ve 4) ile Tablo 1 ve 2 yardımı ile ikili karşılaştırma matrislerinin güvenirlik ve geçerliliklerinin hesaplandığı öncelik vektörlerinin tutarlılık oranlarının analizi, ve son olarak her bir ana kriter ağırlığı ile varsa içerdiği alt kriterlerin ağırlıklarının çarpılarak hesaplanan küresel ağırlıkların belirlenmesi adımıdır (Supçiller ve Çarpraz, 2011: 6-9).

$w_{i}=\frac{\prod_{j=1}^{n} a_{i j}^{1 / n}}{\sum\left(\prod_{j=1}^{n} a_{i j}^{1 / n}\right)}$ $\mathrm{l}_{\max }=\frac{\sum_{\mathrm{i}=1}^{\mathrm{n}} \frac{\mathrm{d}}{\mathrm{w}_{i}}}{\mathrm{n}}$

Tutarlılık Göstergesi $\left(T I_{A}\right)=\frac{l_{\max -\mathrm{n}}}{\mathrm{n}-1}$

Tutarlılık Oranı $(T O)_{\mathrm{A}}=\frac{\mathrm{TI}_{\mathrm{A}}}{\mathrm{RI}_{\mathrm{n}} *}$

Tablo 2. Rassal İndeks Tablosu

\begin{tabular}{cc}
\hline $\mathrm{N}$ & $\mathrm{RI}$ \\
\hline 3 & 0,58 \\
4 & 0,9 \\
5 & 1,12 \\
6 & 1,24 \\
7 & 1,32 \\
8 & 1,41 \\
9 & 1,45 \\
10 & 1,49 \\
11 & 1,51 \\
\hline
\end{tabular}

Kaynak: Podvezko (2009: 184)

\section{Bulgular}

Çalışma kapsamında bir kamu üniversitesindeki 11 akademisyen ile ana ve alt faktörler için yapılan ikili karşılaştırmaların geometrik ortalamaları alınarak nihai iki karşılaştırma tabloları oluşturulmuştur. Aşağıdaki tablolarda sırasıyla ana faktörlerin nihai ikili karşılaştırması ve her bir ana faktöre ait olan alt faktörlerin ikili karşılaştırması yer almaktadir.

Tablo 3. Ana Faktörlerin Nihai İkili Karşılaştırmaları ve Faktör Ağırlıkları

\begin{tabular}{|c|c|c|c|c|c|}
\hline Ana Faktörler & $\mathrm{C} 1$ & $\mathrm{C} 2$ & $\mathrm{C} 3$ & Geo. Ort. & $\begin{array}{c}\text { ÖV } \\
\text { (A } \breve{g} ı r l ı k l a r)\end{array}$ \\
\hline Bireysel (C1) & 1,00 & 1,39 & 2,16 & 1,44 & 0,4635 \\
\hline Grupsal (C2) & 0,72 & 1,00 & 1,00 & 0,90 & 0,2878 \\
\hline Örgütsel (C3) & 0,46 & 1,00 & 1,00 & 0,77 & 0,2487 \\
\hline $\mathrm{TI}$ & 0,011 & $\mathrm{RI}$ & 0,58 & $\mathrm{TO}$ & $0,02 \leq 0,1$ \\
\hline \multicolumn{2}{|c|}{$\mathrm{TI}=$ Tutarlık İndeksi } & \multicolumn{2}{|c|}{$\begin{array}{l}\mathrm{RI}=\text { Rassal } \\
\text { İndeks }\end{array}$} & \multicolumn{2}{|c|}{$\mathrm{TO}=$ Tutarlık Oranı } \\
\hline
\end{tabular}

Yukarıdaki tabloda sosyal kaytarma davranışını etkileyen ana faktörler olan sirasiyla; bireysel faktör (C1), grupsal faktör (C2) ve örgütsel faktörün (C3) 11 akademisyen tarafından yapılmış olan ikili karşılaştırmalarının geometrik ortalamaları yer almaktadır. Bu çerçevede, bu ana kriterlerin öncelik vektörleri (ağırlıkları) eşitlik (1) yardımı ile hesaplanmış olup, matrisin tutarlılık oranı ise eşitlik (2, 3 ve 4) yardımı ile elde edilerek 0,02 olarak hesaplanmıştır. Matrise göre en önemli ana faktör \% 46,35'lik önem derecesi ile bireysel faktörlerdir.

Tablo 4'te sosyal kaytarma davranışını etkileyen ana faktörlerden ilki olan bireysel faktörlerin alt faktörleri sırasıyla; cinsiyet (c11), kıdem/unvan (c12), kişilik (c13), kültür (c14), tükenmişlik seviyesi (c15) ve örgütsel bağlılık seviyesinin (c16), 11 akademisyen tarafindan yapılmış olan ikili karşılaştırmalarının geometrik ortalamaları yer almaktadır. Bu çerçevede, bu alt kriterlerin öncelik vektörleri (ağırlıkları) eşitlik (1) yardımı ile hesaplanmış olup, matrisin tutarlılık oranı ise eşitlik (2, 3 ve 4$)$ yardımı ile elde edilerek 0,05 olarak hesaplanmıştır. Matrise göre en önemli alt faktör \%28,16'lık önem derecesi ile kişilik olmuştur. 
Tablo 4. Bireysel Ana Faktörü Altındaki Alt Faktörlerin Nihai İkili Karşılaştırmaları ve Faktör Ağırlıkları

\begin{tabular}{|c|c|c|c|c|c|c|c|c|}
\hline Bireysel Faktörler & $\mathrm{c} 11$ & $\mathrm{c} 12$ & $\mathrm{c} 13$ & $\mathrm{c} 14$ & $\mathrm{c} 15$ & $\mathrm{c} 16$ & Geo. Ort. & ÖV (Ağırlıklar) \\
\hline Cinsiyet (c11) & 1,00 & 0,35 & 0,17 & 0,33 & 0,16 & 0,22 & 0,30 & 0,0415 \\
\hline Kidem/Unvan (c12) & 2,87 & 1,00 & 0,56 & 0,40 & 0,65 & 0,51 & 0,77 & 0,1082 \\
\hline Kişilik (c13) & 6,04 & 1,78 & 1,00 & 4,62 & 0,74 & 1,78 & 2,01 & 0,2816 \\
\hline Kültür (c14) & 3,00 & 2,52 & 0,22 & 1,00 & 0,43 & 0,74 & 0,90 & 0,1257 \\
\hline Tükenmişlik Seviyesi (c15) & 6,43 & 1,54 & 1,35 & 2,33 & 1,00 & 1,19 & 1,83 & 0,2561 \\
\hline Örgütsel Bağl1lık Seviyesi (c16) & 4,48 & 1,97 & 0,56 & 1,35 & 0,84 & 1,00 & 1,33 & 0,1869 \\
\hline Tİ & 0,06 & & RI & $=$ & 1,24 & & $\mathrm{TO}$ & $0,05 \leq 0,1$ \\
\hline \multicolumn{3}{|c|}{$\mathrm{TI}=$ Tutarlık İndeksi } & \multicolumn{3}{|c|}{$\mathrm{R} \dot{\mathrm{I}}=$ Rassal İndeks } & \multicolumn{3}{|c|}{$\mathrm{TO}=$ Tutarlık Oranı } \\
\hline
\end{tabular}

Tablo 5. Grupsal Ana Faktörü Altındaki Alt Faktörlerin Nihai İkili Karşılaştırmaları ve Faktör Ağırlıkları

\begin{tabular}{|c|c|c|c|c|c|c|c|c|c|c|}
\hline Grupsal Faktörler & c21 & $\mathrm{c} 22$ & $\mathrm{c} 23$ & $\mathrm{c} 24$ & $\mathrm{c} 25$ & $\mathrm{c} 26$ & $\mathrm{c} 27$ & $\mathrm{c} 28$ & Geo.Ort. & ÖV (Ăgırlıklar) \\
\hline Diğerlerinin SKD* Sergilemesi (c21) & 1,00 & 1,28 & 0,61 & 0,65 & 1,38 & 0,57 & 0,96 & 0,55 & 0,82 & 0,0976 \\
\hline Kişilerarası Güven (c22) & 0,78 & 1,00 & 0,26 & 0,64 & 0,75 & 0,37 & 0,80 & 0,42 & 0,57 & 0,0682 \\
\hline Grupiçi Çabanın Önemsenmemesi (c23) & 1,65 & 3,87 & 1,00 & 1,32 & 1,60 & 1,25 & 1,65 & 0,99 & 1,51 & 0,1794 \\
\hline Kişilerarası Koordinasyon Eksikliği (c24) & 1,54 & 1,57 & 0,76 & 1,00 & 1,86 & 1,29 & 1,57 & 0,58 & 1,19 & 0,1412 \\
\hline Grubun Büyüklüğü (c25) & 0,72 & 1,33 & 0,63 & 0,54 & 1,00 & 0,61 & 0,52 & 0,44 & 0,68 & 0,0803 \\
\hline Rol Belirsizliği (c26) & 1,77 & 2,72 & 0,90 & 0,78 & 1,64 & 1,00 & 1,38 & 1,05 & 1,28 & 0,1515 \\
\hline Grup Kaynaşması (c27) & 1,04 & 1,25 & 0,61 & 0,64 & 1,94 & 0,72 & 1,00 & 0,95 & 0,95 & 0,1128 \\
\hline Amaç Birliği Yoksunluğu (c28) & 1,81 & 2,39 & 1,01 & 1,71 & 2,30 & 0,95 & 1,05 & 1,00 & 1,42 & 0,1690 \\
\hline \multirow{2}{*}{\multicolumn{4}{|c|}{ TI $=$ Tutarlık İndeksi }} & & RI & 1,4 & & & $\mathrm{O}$ & $0,01 \leq 0,1$ \\
\hline & & & & \multicolumn{4}{|c|}{$\mathrm{RI}=$ Rassal İndeks } & \multicolumn{3}{|c|}{$\mathrm{TO}=$ Tutarlık Oran 1} \\
\hline
\end{tabular}

*Sosyal Kaytarma Davranışları

Tablo 5'te sosyal kaytarma davranışını etkileyen ana faktörlerden ikincisi olan grupsal faktörlerin alt faktörleri sırasıyla; gruptaki diğer üyelerin sosyal kaytarma davranışı sergilemesi (c21), kişilerarası güven (c22), grup içi çabanın önemsenmemesi (c23), kişilerarası koordinasyon eksikliği (c24), grubun büyüklüğü (c25), rol belirsizliği (c26), grup kaynaşması (c27) ve amaç birliği yoksunluğunun (c28), 11 akademisyen tarafından yapılmış olan ikili karşılaştırmalarının geometrik ortalamaları yer almaktadır. $\mathrm{Bu}$ çerçevede, bu alt kriterlerin öncelik vektörleri (ağırlıkları) eşitlik (1) yardımı ile hesaplanmış olup, matrisin tutarlılık oranı ise eșitlik (2, 3 ve 4$)$ yardımı ile elde edilerek 0,01 olarak hesaplanmıştır. Matrise göre en önemli alt faktör $\% 17,94$ lük önem derecesi ile grup içi çabanın önemsenmemesi olmuştur.

Tablo 6. Örgütsel Ana Faktörü Altındaki Alt Faktörlerin Nihai İkili Karşılaştırmaları ve Faktör Ağırlıkları

\begin{tabular}{|c|c|c|c|c|c|c|c|}
\hline Örgütsel Faktörler & $\mathrm{c} 31$ & $\mathrm{c} 32$ & $\mathrm{c} 33$ & $\mathrm{c} 34$ & $\mathrm{c} 35$ & Geo.Ort. & ÖV (Ağırlıklar) \\
\hline Çalışma Koşulları (c31) & 1,00 & 0,75 & 0,35 & 1,00 & 0,88 & 0,74 & 0,1421 \\
\hline Ödüllendirme Sisteminin Eksikliği (c32) & 1,34 & 1,00 & 0,61 & 0,98 & 0,90 & 0,94 & 0,1792 \\
\hline Örgütsel Adaletsizlik (c33) & 2,89 & 1,64 & 1,00 & 1,85 & 1,67 & 1,71 & 0,3271 \\
\hline Örgütsel Kültür (c34) & 1,00 & 1,02 & 0,54 & 1,00 & 0,76 & 0,84 & 0,1610 \\
\hline Grup içi ve Gruplararası Rekabet Seviyesi (c35) & 1,14 & 1,11 & 0,60 & 1,31 & 1,00 & 1,00 & 0,1906 \\
\hline $\mathrm{TI}=0,01$ & & \multicolumn{4}{|c|}{$\mathrm{R} \dot{\mathrm{I}}=1,12$} & \multicolumn{2}{|c|}{$\mathrm{TO}=0,01 \leq 0,1$} \\
\hline Tİ=Tutarlık İndeksi & & ssal İn & & & & $\operatorname{arl} 1 \mathrm{k} O$ & \\
\hline
\end{tabular}

Tablo 6'da sosyal kaytarma davranışını etkileyen ana faktörlerden sonuncusu olan örgütsel faktörlerin alt faktörleri sırasıyla; çalışma koşulları (c31), ödüllendirme sisteminin eksikliği (c32), örgütsel adaletsizlik (c33), örgütsel kültür (c34) ile grup içi ve gruplararası rekabet seviyesinin (c35), 11 akademisyen tarafından yapılmış olan ikili karşılaştırmalarının geometrik ortalamaları yer almaktadır. Bu çerçevede, bu alt kriterlerin öncelik vektörleri (ağırlıkları) eşitlik (1) yardımı ile hesaplanmış olup, matrisin tutarlılık oranı ise eşitlik (2, 3 ve 4$)$ yardımı ile elde edilerek 0,01 olarak hesaplanmıştır. Matrise göre en önemli alt faktör \%32,71'lik önem derecesi ile örgütsel adaletsizlik olmuştur.

Tablo 7'de yapılan analiz neticesinde küresel ağırlıklara bakıldığında ana faktörler kapsamında, bireysel, grupsal ve örgütsel faktörler temelinde \%46'lık önem derecesi ile bireysel faktörlerin sosyal kaytarma üzerinde en etkili faktör olduğu bulunmuştur. Ayrıca alt faktör bağlamında küresel ağırlık bakımından (nihai sonuçlara göre) kişilik (\%13) ve tükenmişlik seviyesi (\%12) ilk grupta sosyal kaytarmaya en çok etki eden kriterler olurken; ikinci grupta örgütsel bağlılık
$(\% 8,66)$ ve örgütsel adaletsizlik $(\% 8,13)$ seviyesi yer almaktadır. Diğer davranışlar benzer ağırlıklara sahip olduğundan ve aşağıdaki ağırlık grafiğindeki çizginin yatay seyir almasından dolayı bu faktörler üzerinde detaylıca durulmamıştır. 
Şekil 2. Sosyal Kaytarma Davranışını Belirleyen Faktörlerin Küresel Ağırlık Grafiği

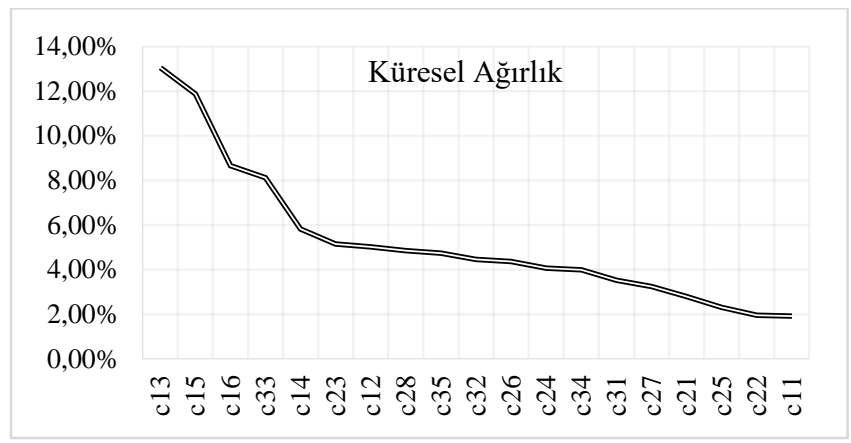

Tablo 7. Sosyal Kaytarma Davranışlarını Etkileyen Faktörlerin Küresel Ağırlıkları

\begin{tabular}{|c|c|c|c|c|c|}
\hline $\begin{array}{c}\text { Ana } \\
\text { Faktörler }\end{array}$ & Ağırlıklar & $\begin{array}{c}\text { Alt } \\
\text { Faktörler }\end{array}$ & Ağırlıklar & $\begin{array}{c}\text { Küresel } \\
\text { Ağırlıklar }\end{array}$ & $\begin{array}{c}\text { Hiyerarşideki } \\
\text { Yer }\end{array}$ \\
\hline \multirow{6}{*}{$\mathrm{C} 1$} & \multirow{6}{*}{0,4635} & c11 & 0,0415 & $\% 1,92$ & 19 \\
\hline & & $\mathrm{c} 12$ & 0,1082 & $\% 5,02$ & 7 \\
\hline & & c13 & 0,2816 & $\% 13,05$ & 1 \\
\hline & & c14 & 0,1257 & $\% 5,83$ & 5 \\
\hline & & $\mathrm{c} 15$ & 0,2561 & $\% 11,87$ & 2 \\
\hline & & c16 & 0,1869 & $\% 8,66$ & 3 \\
\hline \multirow{8}{*}{$\mathrm{C} 2$} & \multirow{8}{*}{0,2878} & c21 & 0,0976 & $\% 2,81$ & 16 \\
\hline & & $c 22$ & 0,0682 & $\% 1,96$ & 18 \\
\hline & & $c 23$ & 0,1794 & $\% 5,16$ & 6 \\
\hline & & c24 & 0,1412 & $\% 4,07$ & 12 \\
\hline & & c25 & 0,0803 & $\% 2,31$ & 17 \\
\hline & & c26 & 0,1515 & $\% 4,36$ & 11 \\
\hline & & c27 & 0,1128 & $\% 3,25$ & 15 \\
\hline & & c28 & 0,1690 & $\% 4,86$ & 8 \\
\hline \multirow{5}{*}{$\mathrm{C} 3$} & \multirow{5}{*}{0,2487} & c31 & 0,1421 & $\% 3,53$ & 14 \\
\hline & & c32 & 0,1792 & $\% 4,46$ & 10 \\
\hline & & c33 & 0,3271 & $\% 8,13$ & 4 \\
\hline & & c34 & 0,1610 & $\% 4,00$ & 13 \\
\hline & & c35 & 0,1906 & $\% 4,74$ & 9 \\
\hline
\end{tabular}

Elde edilen bulgulardan hareketle öne çıkan 5 temel kriter ana faktör bazında bireysel özellikler olurken, alt faktör bazında kişilik, tükenmişlik seviyesi, örgütsel bağlılık ve örgütsel adaletsizlik şeklinde gerçekleşmiştir. Bu faktörlerin ön plana çıkması, sosyal kaytarma açısından önemi ve sosyal kaytarmaya ilişkin neler yapılabileceği hususunda ise:

(i) Bireysel faktörlerin en etkili faktör olarak bulunması bireyin kişisel özellikleri, tembellikleri, inanışları, işlerine atfettikleri anlam vb. gibi unsurlarla açıklanabilir. Sosyal kaytarma davranışının ahlaki ve bireysel boyutlarının daha ağır bastığı bu sonucu doğurmuş olabilir.

(ii) Bireysel faktörlerden yaş ve cinsiyet gibi doğuştan gelen faktörlerin yanı sıra oluşumunda bir grup dinamiğinin hâkim olduğu ve sosyal çevrenin etkisi ile şekillenen kişilik, sosyal kaytarma davranışı üzerinde etkili olan bir diğer faktördür. Kişilik özellikleri bireyin toplum içinde sosyal yaşantıda ve ikili ilişkilerinde önemli bir belirleyici olarak karşımıza çıkmaktadır. Buradan hareketle bireylerin kişilik örüntüleri ve yapılarının sosyal kaytarma üzerinde diğer faktörlere kıyasla daha çok belirleyici olduğu sonucuna ulaşıldığı ifade edilebilir.

(iii) Tükenmişlik, sosyal kaytarma davranışı üzerinde en etkili olan faktörlerden bir başkası, mesleki tükenmişlik yaşayan bireyin iş yapması, sorumluluklarını yerine getirme noktasında kendisini geri çekmesi gibi durumlarla karşı karşıya kalınabilmektedir.

(iv) Örgütsel bağlılığın sosyal kaytarma üzerindeki etkisi kurumsal aidiyet duygusu ile açıklanabilir. Bireylerin mensubu oldukları kuruma, çalışma ortamına kendilerini ait hissetmeleri ve bu hissiyat ile daha verimli ve etkin çalışabilecekleri düşünülmektedir. Örgütsel bağlılı̆̆1 gelişmemiş olan bireylerin kendilerini dışlanmış ve örgütten ayrı düşünmeleri neticesinde sosyal kaytarma davranış1 sergileyebildikleri düşünülmektedir.

(v) Örgütsel adaletsizliğin sosyal kaytarma üzerindeki etkisine bakıldığında örgüt içinde personele adil ve liyakate dayalı davranılmaması, iş paylaşımının ve sorumluluk dağılımının iş barışını bozacak şekilde düzenlenmesi ile ilgili olduğu söylenebilir. Örgüt içinde görev dağılımı yapılırken personele sorumluluk verilirken mesleki yeterlilik ve uzmanlık alanının göz ardı edilmesi örgütsel adaletsizliği doğurabileceği gibi sonrasında da sosyal kaytarma davranışının sergilenmesi üzerinde etkileyici bir unsur olarak görülebilir.

\section{Sonuç}

$\mathrm{Bu}$ çalışmada sosyal kaytarmaya etki eden faktörler sıralanmış, ana faktör bazında en önemli etkileyici faktörün bireysel özellikler olduğu bulunmuştur. Doğan vd. (2012: 72) ve Tolukan vd.'nin (2017: 7) ortaya koydukları çalışmada kişilerin bireysel özellik farklılıklarının sosyal kaytarma üzerinde etkisi olduğu sonucuna ulaşılmıştır. Araştırma bulguları ile aynı doğrultuda sonuçlar olduğu ifade edilebilir. Kişilik, sosyal kaytarma üzerinde belirleyici olan faktörler arasında bulunmuştur. Bu doğrultuda Pabico vd. (2008: 25) tarafından yapılan çalışmada baskın kişilik örüntüsüne sahip kimseler ve sosyal kaytarma arasında pozitif bir ilişki olduğu sonucuna ulaşılmıştır. Ek olarak Tan ve Tan (2008) tarafından yapılan çalışmada da kişiliğin, çalışkanlığın ve sorumluluk sahibi olma gibi durumların sosyal kaytarma üzerinde belirleyici olduğu bulgusu elde edilmiştir.

Tükenmişlik düzeyinin yüksek olmasının sosyal kaytarma üzerinde etkili olabileceği bu araştırma sonuçlarında belirlenmiştir. Yapılan diğer çalışmalara bakıldığında Budak ve Süregevil (2005: 45) tarafından akademik personelin tükenmişliğine dair yapılan çalışmada tükenmişliğin önemli bir problem olduğu bunun yanı sıra örgütsel aidiyet, iş yükü ve örgütsel adalet gibi unsurların da tükenmişlik üzerinde etkisinin olduğu ve bireylerin performansı noktasında belirleyici olduğu sonucuna ulaşılmıştır. Ceylan vd. (2015: 57) çalışmasında tükenmişlik odağında yaptığı bir diğer çalışmada da örgütsel faktörlerin ve bireyin çalışma performansının tükenmişlik düzeyi ile doğrudan ilişkili olduğu belirlenmiştir. Uysal (2016: 738) tarafindan tükenmişlik ve sosyal kaytarma ilişkisini ölçmek üzere yapılan çalışmada tükenmişlik ve sosyal kaytarma arasında pozitif yönlü bir ilişki olduğu bulgusu elde edilmiştir. $\mathrm{Bu}$ araştırmanın sonuçları ile literatürdeki diğer çalışmaların benzerlik gösterdiği söylenebilir.

Bir diğer sosyal kaytarma davranışı belirleyicisi olan unsur da örgütsel bağlılık seviyesidir. Şeşen ve Kahraman (2014: 43) tarafından yapılan araştırmada bireyin örgütsel bağlılığı ile sosyal kaytarma arasında negatif bir ilişki bulunmuştur. 
$\mathrm{Bu}$ bağlamda bu çalışmanın sonucunda örgütsel bağlılık düzeyinin düşük olmasının sosyal kaytarmaya neden olabileceği sonucu desteklenmiştir.

Bir başka sosyal kaytarmayı etkileyen unsur ise örgütsel adaletsizliktir. Örgütsel adalet odağında Demirel (2009: 151) tarafından yönetici ve çalışanlar üzerinde gerçekleştirilen çalışmada örgütsel adaletin sağlanması halinde iş birliği, iletişim ve iş barışının daha iyi düzeylerde olabileceği sonucuna ulaşılmıştır. Uslu ve Çavuş (2014: 53) çalışmalarında örgütsel adaletin sosyal kaytarma davranışının belirleyicilerinden bir tanesi olduğu bulgusu elde edilmiştir. $\mathrm{Bu}$ çalışmanın sonuçlarının literatürdeki diğer çalışmaların sonucu ile örgütsel adalet noktasında benzerlik gösterdiği ifade edilebilir.

$\mathrm{Bu}$ çalışmanın bazı kısıtları bulunmaktadır. Öncelikle çalışmanın yapıldığı kamu üniversitesinde sosyal kaytarmanın var olup olmadığı ölçülmemiş, akademisyenlikte grup çalışmasının önemli olduğu bilgisinden yola çıkılarak, bu tür davranışa etki eden faktörler hiyerarşik olarak sıralanmıştır. Ayrıca çalışma sadece kamu sektöründeki tek bir üniversitede uygulanmıştır. Sosyal kaytarma davranışına etki eden faktörler birbirlerinden bağımsız olacak şekilde değerlendirilmiştir.

Araştırmanın sonuçları 1şığında aşağıdaki önerilere yer verilmiştir:

(i) Sosyal kaytarma davranışının ortak yürütülen işler bağlamında diğer grup ve örgüt üyelerine yönelik haksızlık edildiği bilincinin oluşturulmasına yönelik farkındalık eğitimleri ve hizmet içi eğitimleri yapılması önerilebilir. Akademi etiği ve akademide grup çalışmasına dair bilgiler akademik kitle ile paylaşılabilir.

(ii) Başka kamu ve hatta özel üniversitelerde konu yeniden araştırılarak karşılaştırma yapılabilir. $\mathrm{Bu}$ bağlamda kriterler arasındaki olası ilişkiler DEMATEL yöntemi ile belirlenip, AHP yerine Analitik Ăg Prosesi (AAP) ile veriler yeniden analiz edilebilir.

(iii) Kişilik açısından değerlendirme yapıldığında birebir görüşme ve telkin yoluyla çalışmalar yapılması psiko-sosyal açıdan personelin desteklenmesi önerilebilir. Psiko-sosyal destek bağlamında üniversitelerin Danışma, Rehberlik Uygulamaları ve Araştırma Merkezlerinde bilimsel ve mesleki destek sağlanabilir.

(iv) Tükenmişlik temelli sosyal kaytarma davranışının engellenebilmesi için personelin moral ve motivasyonunu yükseltecek örgüt içi ve örgüt diş1 etkinliklerin planlanması ve uygulanması önerilebilir. Kamu üniversitelerinde uygulanan akademik teşvik gibi motivasyonu artıcı uygulamalar geliştirilebilir. Örgüt dişı ortak çalışmalara, kongre vb. gibi faaliyetlere sunulan destekler artırılabilir.

(v) Örgütsel bağlılığın artırılması, personelin kurumsal aidiyetinin oluşması için benlik saygısını artırıcı ve bireyin yaptığı işten dolayı bir saygınlığının olduğunu personele verilecek ödül ve destekleyici belge sistemi ile yansitılması önerilebilir. Akademik atama ve yükseltilme kriterlerinde de bu konuya daha fazla atıfta bulunulabilir. (vi) Örgütsel adaletin sağlanması için örgüt yönetici ve personellerinin arasında iş barışının kurulması adına adaletli ve liyakate dayalı iş paylaşımının yapılması önerilebilir. Kamu üniversitelerinde yapılan atamalar ve görevlendirmelerde bu durum daha fazla önem atfedilerek daha iyi bir konuma taşınabilir.

(vii) Sosyal kaytarma literatürüne sunulan katkıyı artırmak adına daha geniş çalışma grupları ve araştırma örneklemlerinde benzer çalışmaların yaygınlaştırılması ve yapılması önerilebilir. YÖK' e bağlı tüm üniversiteler bu çalışma kapsamına alınabilir.

\section{Kaynakça}

Acar, A., Nemutlu, E., Gürhan, G., \& Liman, V. (2004). Hacettepe Üniversitesi Eczacılık Fakültesi Araştırma Görevlilerinin İş Memnuniyeti ve Bunu Etkileyen Faktörler. Hacettepe Üniversitesi Eczacılık Fakültesi Dergisi, 24(2), 95-106.

Alam, K., Ali, A., Ali, N., \& Zaman, G. (2014). Organizational Justice, Task Enjoyment, Leadership style and Organizational Culture as Strategies for Reduction of Social Loafing. Abasyn University Journal of Social Sciences, 7(1), 77-99.

Balcı, O. (2016). Ilkögretim okullarında görev yapan ögrretmenler ve yöneticilerin örgütsel sinizm, kendini işe verememe (presenteizm) ve sosyal kaytarma arasindaki ilişkinin incelenmesi (Arnavutköy İç̧esi Örneği). Doktora Tezi. İstanbul: İstanbul Arel Üniversitesi.

Baş, T. (2002). Öğretim Üyelerinin İş Tatmin Profillerinin Belirlenmesi, DEÜ İktisadi ve İdari Bilimler Fakültesi Dergisi, 17(2), 19-37.

Budak, G., \& Sürgevil, O. (2005). Tükenmişlik ve Tükenmişliği Etkileyen Örgütsel Faktörlerin Analizine İlişkin Akademik Personel Üzerinde Bir Uygulama. DEÜ İktisadi ve İdari Bilimler Fakültesi Dergisi, 2, 95108.

Candan, H., \& İnce, M. (2016). Siber Kaytarma ve Örgütsel Bağlılık Arasındaki İlişkinin İncelenmesine Yönelik Emniyet Çalışanları Üzerine Bir Araştırma. Niğde Üniversitesi İktisadi ve İdari Bilimler Dergisi, 9(1), 229235.

Ceylan, H., Gül, N., \& Öksüz, M. (2016). Sosyal Çalışmacılarda İş Doyumu ve Tükenmişliğe Etki Eden Faktörlerin Sosyal Hizmet Alanlarına Göre Karşılaştırmalı İncelenmesi. Yalova Üniversitesi Sosyal Bilimler Dergisi, 11, 43-69.

Crawford, G., \& Williams, C. (1985). The analysis of subjective judgment matrices. Project Air Force Report Prepared for the United States Air Force, 1-34.

Çelikten, M. (2003). Akademisyenlerin Mesleki Yardımlaşması: Erciyes Üniversitesi Örneği. Amme Ídaresi Dergisi, 36(2), 101-121.

Demirel, Y. (2009). Örgütsel Adaletin Yönetici-Çalışan İlişkileri Üzerine Etkisi: Farklı Sektör Çalışanlarına Yönelik Bir Araştırma. Sosyal ve Ekonomik Araştırmalar Dergisi, 17, 137-154. 
Doğan, A., Bozkurt, S., \& Demir, R. (2012). Sosyal Kaytarma Davranışı İle Algılanan Görev Görünürlüğü Arasındaki İlişkinin İncelenmesine Yönelik Bir Araştırma. SÜ İ̈BF Sosyal ve Ekonomik Araştırmalar Dergisi, 244, 53-79.

Dong, Q., \& Cooper, O. (2016). A Peer To Peer Dynamic Adaptive Consensus Reaching Model For The Group Ahp Decision Making. European Journal of Operational Research, 250(2), 521-530. http://dx.doi.org/10.1016/j.ejor.2015.09.016

Eikenhout, N.R. (2004). The Effects of Task Structure and Group Target Monetary Incentives on Social Loafing, Dissertation for the Degree of Doctor of Philosophy: Department of Psychology. USA: Western Michigan University.

Etemadi, M., Darab, M., Khorasani, E., Moradi, F., \& Vazirinasab, H. (2015). Social loafing among nurses and its relation with organizational justice. International Journal Education Psychologic Researches, 1, 125-130.

Gencel, U. (2001). Yükseköğretim Hizmetlerinde Toplam Kalite Yönetimi ve Akreditasyon. D.E. U. Sosyal Bilimler Enstitüsü Dergisi, 3(3), 164-218.

Gök, G.A., \& Koca, D. (2016). Sağlık Çalışanlarında Hiyerarşi ve Takım Eğiliminin Sosyal Kaytarmaya Etkisi: Isparta İlçe Hastaneleri Örneği. Mehmet Akif Ersoy Üniversitesi Sosyal Bilimler Enstitüsü Dergisi, 17, 354-375.

Haugen, T., Reinboth, M., Hetlelid, K.J., Peters, D.M., \& Hoigaard, R. (2016). Mental Toughness Moderates Social Loafing Ġn Cycle Time-Trial Performance. Research Quarterly For Exercıse And Sport, 87(3), 305310.

Hoigaard, R., \& Ingvaldsen, R.P. (2006). Social Loafing in Interactive Groups: The Effects of Identifiability on Effort and Individual Performance in Floorball. The online Journal of Sport Psychology, 8 (2), 52-63.

Ilgın, B. (2013). Toplumsal Bir Hastalık: Sosyal Kaytarma. Uşak Üniversitesi Sosyal Bilimler Dergisi, 6(3), 238-270.

Ingham, A.G., Levinger, G., Graves, J., \& Peckham, V. (1974). The Ringelmann Effect: Studies of group size and group performance. Journal Of Experimental Social Psychology, 10(4), 371-384.

Kafes, M., \& Kaya, Ş.D. (2017). Sosyal Kaytarma Davranışı Üzerine Yapılmış Çalışmaların İncelenmesi. Türk \& İslam Dünyası Sosyal Araştırmalar Dergisi, 11, 227-245.

Karaman, F., \& Altunoğlu, A. E. (2007). Kamu üniversiteleri öğretim elemanlarının iş tatmini düzeyini etkileyen faktörler. Yönetim ve Ekonomi: Celal Bayar Üniversitesi İktisadi ve İdari Bilimler Fakültesi Dergisi, 14(1), 109120.

Karau, S. J., \& Hart, J. W. (1998). Group cohesiveness and social loafing: Effects of a social interaction manipulation on individual motivation within groups. Group Dynamics: Theory, Research, and Practice, 2(3), 185-191. http://dx.doi.org/10.1037/10892699.2.3.185
KC, B., Stainback, G. A., \& Chhetri, B. B. K. (2014). Community users' and experts' perspective on community forestry in Nepal: a SWOT-AHP analysis. Forests, Trees and Livelihoods, 23(4), 217-231. https://doi.org/10.1080/14728028.2014.929982

Kesen, M. (2015). Psikolojik güçlendirme çalışanların sosyal kaytarma davranışlarını azaltır mı?. Journal of Yaşar University, 10(38), 6531-6540.

Koçel, T. (2014). İşletme Yöneticiliği. İstanbul: Beta Yayınevi.

Latane, B., Williams, K., \& Harkins, S. (1979). Many Hands Make Light the Work: The Causes and Consequences of Social Loafing. Journal of Personality and Social Psychology, 37(6), 822-832.

Öge, H.S., \& Kurnaz, G. (2017). Presenteeism İle Sosyal Kaytarma Arasındaki İlişki: Otomotiv İşletmesinde Bir Araştırma. International Journal of Academic Value Studies (Javstudies), 3(16), 115-129.

Özmutaf, N. M. (2007). Örgütlerde Bireysel Performans Unsurları ve Çatışma. C.Ü. İktisadi ve Idari Bilimler Dergisi, 8(2), 41-60.

Pabico, J.P., Hermocilla, J.A.C., Galang, J.P.C., \& De Sagun, C.D. (2008). Perceived Social Loafing in Undergraduate Software Engineering Teams. Philippine Information Technology Journal, 1(2), 22-28.

Piezon, S. L., \& Ferree, W. D. (2008). Perceptions of social loafing in online learning groups: A study of public university and US Naval War College students. The International Review of Research in Open and Distributed Learning, 9(2), 1-17. http://dx.doi.org/10.19173/irrodl.v9i2.484

Podvezko, V. (2009). Application of ahp technique. Journal of Business Economics and Management, 10(2), 181189.

Saaty, T. L. (1991). Some mathematical concepts of the analytic hierarchy process. Behaviormetrika, 18(29), 1-9.

Saaty, T. L., \& Zoffer, H. J. (2012). A New Approach to the Middle East Conflict: The Analytic Hierarchy Process. Journal of Multi-Criteria Decision Analysis, 19,201-225.

Schippers, M.C. (2014). Social Loafing Tendencies and Team Performance: The Compensating Effect of Agreeableness and Conscientiousness. Academy of Management Learning \& Education, 1, 62-81.

Simms, A., \& Nichols, T. (2014). Social Loafing: A Review of the Literature. Journal of Management Policy and Practice, 15(1), 58-67.

Supçiller, A. A., \& Çapraz, O. (2011). Ahp-topsıs yöntemine dayalı tedarikçi seçimi uygulaması. Ístanbul Üniversitesi Iktisat Fakültesi Ekonometri ve İstatistik Dergisi, 13, 122.

Surapati, P., \& Mukhopadhyaya, D. (2011). Grey relational analysis based intuitionistic fuzzy multi-criteria group decision making approach for teacher selection in higher education. International Journal of Computer Applications, 34(10), 21-29. 
Şeşen, H., \& Kahraman, Ç.A. (2014). İş Arkadaşlarının Sosyal Kaytarmasının, Bireyin İş Tatmini, Örgütsel Bağlılık ve Kendi Kaytarma Davranışlarına Etkisi. İş ve Insan Dergisi, 1, 43-51.

Tan, H.H., \& Tan, M.L. (2008). Organizational citizenship behavior and social loafing: The role of personality, motives, and contextual factors. The Journal of Psychology, 142(1),89-108.

Thompson, R.B., \&Thornton, B. (2014). Gender and Theory of Mind in Preschoolers' Group Effort: Evidence for Timing Differences Behind Children's Earliest Social Loafing. The Journal of Social Psychology, 154, 475479. https://doi.org/10.1080/00224545.2014.933763

Tolukan, E., Bayrak, M., \& Karacan Doğan, P. (2017). Antrenörlerin Sosyal Kaytarma Algilarının İncelenmesi. Gaziantep Üniversitesi Spor Bilimleri Dergisi, 2(1), 113.

Triantaphyllou, E., \& Mann, S. H. (1995). Using the analytic hierarchy process for decision making in engineering applications: some challenges. International Journal of Industrial Engineering: Applications and Practice, 2(1), 35-44.

Uslu, Y.D., \& Çavuş, M.F. (2014). Örgütsel Adalet ve Kaytarma Davranışları. Ordu Üniversitesi Sosyal Bilimler Araştırmaları Dergileri, 7, 51-54.

Uysal, H. T. (2016). Örgütlerde Sosyal Kaytarma Algısının Çalışanların Tükenmişlik Duygusuna Etkisi. 3. Ulusal Meslek Yüksekokulları Sosyal ve Teknik Bilimler Kongresi, 732-743.

Ünal, Ö. F. (2011). Analitik Hiyerarşi Prosesi ve Personel Seçimi Alanında Uygulamaları. Akdeniz Üniversitesi Uluslararası Alanya İşletme Fakültesi Dergisi, 3 (2), 1838.

Williams, K.D., \& Karau, S.J. (1991). Social Loafing and Social Compensation: The Effects of Expectations of CoWorker Performance. Journal of Personality and Social Psychology, 61 (4), 570-581.

Williams, K.D., \& Karau, S.J. (1993). Social Loafing: A Meta Analytic Review and Theoritical Integration. Journal of Personality and Social Psychology, 65(4), 681-706. 